\title{
PENGARUH PEER EDUCATION TERHADAP MOTIVASI PERSONAL HYGIENE GENETALIA DALAM PENCEGAHAN KANKER SERVIKS PADA WANITA USIA SUBUR
}

\author{
Rini Rahmayanti ${ }^{1}$, Isesreni ${ }^{2}$
}

${ }^{1}$ Dosen Program Studi Ilmu Keperawatan STIKes MERCUBAKTIJAYA Padang Email : rinie.rahmayanti@gmail.com

${ }^{2}$ Dosen Program Studi IImu Keperawatan STIKes MERCUBAKTIJAYA Padang Email : isesreni08@gmail.com

\section{ABSTRACT : THE EFFECT OF PEER EDUCATION ON PERSONAL MOTIVATION OF HYGIENE GENETALIA IN PREVENTION OF CANCER SERVICES IN CHILDBEARING AGED WOMEN}

Background : Cervical cancer is one of the cancers that often attacks women and is a dangerous threat to every woman in the world. One of the causes of cervical cancer is poor genetal hygiene, early prevention that can be done is the provision of health education including using peer eduction methods or peer education.

Purpose : to know the effect of peer education on genetalia personal hygiene motivation in the prevention of cervical cancer in women of childbearing age.

Methods : This type of research is a pre-experimental research with a One Group Pretest-Posttest design with a sample of 10 Childbearing age women. Data were analyzed by paired $t$-test.

Results : The results showed the average motivation before being given peer education was 83.50 with a standard deviation of 8,822 , the average motivation after being given peer education was 105.00 with a standard deviation of 5,715. There is a noticeable difference in mean values between before and after peer education intervention with $p$-value $=0,000(p<0.05$.

Conclusions : there is an effect of peer education on genetalia personal hygiene motivation in the prevention of cervical cancer in women of childbearing age (WUS). It is expected that health services can facilitate peer education programs among WUS to increase motivation in genetal hygiene for the prevention of genetal diseases.

Keywords : Peer education, Motivation, Genitalia hygiene, Childbearing age women

INTISARI : PENGARUH PEER EDUCATION TERHADAP MOTIVASI PERSONAL HYGIENE GENETALIA DALAM PENCEGAHAN KANKER SERVIKS PADA WANITA USIA SUBUR

Pendahuluan : Kanker serviks merupakan kanker yang sering menyerang wanita serta menjadi ancaman berbahaya bagi setiap wanita yang ada diseluruh dunia. Salah satu penyebab kanker serviks adalah hygiene genetalia yang buruk, Pencegahan awal yang dapat dilakukan adalah pemberian pendidikan kesehatan diantaranya menggunakan metode peer eduction atau pendidikan sebaya.

Rini Rahmayanti ${ }^{1}$, Isesreni ${ }^{2}$

${ }^{1}$ Dosen STIKes MERCUBAKTIJAYA Padang. Email : rinie.rahmayanti@gmail.com

${ }^{2}$ Dosen STIKes MERCUBAKTIJAYA Padang. Email : isesreni08@gmail.com 
Tujuan : Diketahuinya pengaruh peer education terhadap motivasi personal hygiene genetalia dalam pencegahan kanker serviks pada wanita usia subur. Metode : Jenis penelitian yang dilakukan adalah pra eksperimental dengan rancangan One Group Pretest-Posttest dengan jumlah sampel 10 WUS. Data dianalisa dengan uji paired t-test.

Hasil : Hasil penelitian didapatkan rata-rata motivasi sebelum diberikan peer education adalah 83.50 dengan standar deviasi 8.822, rata-rata motivasi setelah diberikan peer education adalah 105.00 dengan standar deviasi 5.715. Terlihat ada perbedaan nilai mean antara sebelum dan setelah diberikan intervensi peer education dengan $p$-value $=0,000(p<0.05)$,

Kesimpulan : Ada pengaruh peer education terhadap motivasi personal hygiene genetalia dalam pencegahan kanker serviks pada wanita usia subur (WUS). Diharapkan pelayanan kesehatan dapat memfasilitasi program peer education dikalangan WUS untuk meningkatkan motivasi dalam hygiene genetalia untuk pencegahan dari penyakit genetalia.

\section{Kata Kunci : Peer education, Motivasi, Hygiene genetalia, Wanita Usia Subur}

\section{PENDAHULUAN}

Kanker serviks atau kanker leher Rahim merupakan salah satu kanker yang sering menyerang wanita serta menjadi ancaman berbahaya bagi setiap wanita yang ada diseluruh dunia. Angka kejadian dan tingkat kematian karena kanker serviks cukup tinggi serta diperkirakan akan terus meningkat (Novel, 2010). Kanker serviks menempati urutan pertama dari 10 kanker terbanyak yang ditemukan di 13 pusat laboratorium patologi anatomi yang ada di Indonesia. Indonesia adalah Negara dengan jumlah penderita kanker serviks terbesar di dunia (Kemenkes, 2015). WHO menyebutkan bahwa penderita kanker di dunia bertambah 7 juta setiap tahunnya, dan 2/3 diantaranya ada di Negara-negara yang berkembang.

Menurut Riset Kesehatan Dasar (Riskesdas) tahun 2013 terjadi lonjakan kanker serviks menjadi kanker dengan jumlah terbanyak yang ada di Indonesia yaitu 0,8\% sedangkan kanker payudara berada diurutan kedua yaitu $0,5 \%$. Di Padang provinsi Sumatera Barat juga menempati angka dengan kejadian kanker serviks yang cukup tinggi yaitu 0,9\% (Riskesdas, 2013). Yayasan Kanker Indonesia (2011) menyebutkan bahwa kanker serviks disebabkan oleh Human pappiloma Virus (HPV) yang bisa ditularkan melalui hubungan seks dengan faktor risiko perilaku seksual, merokok, infeksi dari beberapa jenis virus, serta personal hygiene. Personal hygiene organ reproduksi ialah cara untuk mempertahankan atau memperbaiki kesehatan dengan memelihara kebersihan organ reproduksi (Rahmayanti, 2012).

Kanker serviks bisa menyerang wanita dengan berbagai usia, termasuk wanita usia subur. WUS (Wanita Usia Subur) yaitu wanita dimana keadaan organ reproduksinya masih berfungsi dengan baik. WUS berkisar umur 20-45 tahun atau 15-49 tahun. Setiap wanita yang telah melakukan hubungan seksual memiliki resiko terkena kanker serviks. Wanita yang telah berumur seringkali terkena kanker serviks, namun data statistic menunjukkan bahwa kanker serviks juga dapat terjadi pada wanita yang

Rini Rahmayanti ${ }^{1}$, Isesreni ${ }^{2}$

${ }^{1}$ Dosen STIKes MERCUBAKTIJAYA Padang. Email : rinie.rahmayanti@gmail.com

${ }^{2}$ Dosen STIKes MERCUBAKTIJAYA Padang. Email : isesreni08@gmail.com 
berusia antara 20-30 tahun (Diananda, 2009).

Langkah awal atau pencegahan primer yang dapat dilakukan antara lain meningkatkan atau mengintensifikasikan kegiatan promosi kesehatan melalui penyuluhan kepada melalui pemeriksaan pap smear ataupun IVA (inspeksi visual asam asetat) (Hartati, 2010).

Salah satu cara untuk menanggulangi terjadinya kanker serviks adalah dengan cara melakukan personal hygiene genetalia dengan benar, maka perlu motivasi atau dorongan dalam pelaksanaannya. Dorongan atau motivasi dapat diberikan agar WUS dapat dan mau melakukan personal hygiene genetalia yang baik untuk menjaga kebersihan organ reproduksi agar terhindar dari resiko terjadinya kanker serviks (Hartati, 2010).

Salah satu cara untuk meningkatkan motivasi adalah dengan pemberian pendidikan kesehatan diantaranya menggunakan metode peer education. Pendidikan oleh kelompok sebaya merupakan salah satu bentuk dari pendidikan kesehatan dengan cara proses komunikasi, informasi dan edukasi (KIE) yang dilakukan oleh dan untuk kalangan sebaya.

Kelompok sebaya atau peer education adalah suatu proses komunikasi, informasi, dan edukasi (KIE) yang dilakukan oleh kalangan sebaya dan untuk kalangan sebaya itu sendiri. Menurut Rofi'ah (2017), edukasi peer group adalah suatu tindakan perubahan perilaku kesehatan melalui kelompok sebaya, mereka akan berinteraksi dalam kelompok sehingga akan timbul rasa ada kesamaan satu dengan yang lainnya, serta mengembangkan rasa sosial sesuai dengan perkembangan kepribadian. masyarakat supaya menjalankan pola hidup sehat, menghindari faktor resiko penyebab terjadinya kanker, serta melakukan imunisasi dengan vaksin HPV yang diikuti dengan deteksi dini kanker serviks

Keberhasilan pelaksanaan peer education terletak pada peer educator yang terlatih dan berkapabilitas. Peer educator harus dipilih dengan baik dan cermat dengan mempertimbangkan kredibilitasnya dengan kelompok sasaran (Wiratini, 2015).

$$
\text { Sriasih (2013) dalam }
$$

penelitiannya menunjukan bahwa ada perbedaan sangat bermakna antara pengetahuan, sikap dan respon antara responden kelompok remaja yang mendapatkan dengan yang tidak mendapatkan pendidikan seksualitas remaja oleh pendidik sebaya, hasil ini mengartikan bahwa pendidik sebaya mampu mengubah atau mempengaruhi sikap remaja terhadap bahaya seks bebas, sehingga diharapkan mampu mewujudkan derajat kesehatan yang optimal. Menurut penelitian Purwati (2017) tentang pengaruh metode pendidikan sebaya terhadap pengetahuan dan sikap pengendalian HIV/AIDS didapatkan hasil bahwa metode pendidikan sebaya meningkatkan pengetahuan dan sikap pengendalian HIV/AIDS secara signifikan dibandingkan dengan metode ceramah.

Data dari Dinas Kesehatan Kota (DKK) Padang tahun 2017 jumlah wanita usia subur terbanyak ada di wilayah kerja puskesmas Lubuk Buaya Padang kecamatan Koto Tangah. Data dari DKK juga didapatkan bahwa pada tahun 2016 ditemui 17 kasus IVA positif dan curiga kanker serviks sebanyak 2 kasus.

Rini Rahmayanti ${ }^{1}$, Isesreni ${ }^{2}$

${ }^{1}$ Dosen STIKes MERCUBAKTIJAYA Padang. Email : rinie.rahmayanti@gmail.com

${ }^{2}$ Dosen STIKes MERCUBAKTIJAYA Padang. Email : isesreni08@gmail.com 
Tujuan dari penelitian ini adalah untuk mengetahui apakah ada pengaruh pemberian pendidikan kesehatan metode peer education terhadap motivasi personal hygiene genetalia dalam pencegahan kanker serviks pada wanita usia subur.

\section{METODE}

Penelitian ini menggunakan rancangan pre-eksperimental design dengan pendekatan One-Group PrePost test design. Sebelum intervensi diberikan pre-test dan sesudah intervensi diberikan post-test. Intervensi diberikan sebanyak $1 \mathrm{x}$ dalam seminggu dan dilakukan selaman 2 minggu.
Populasi pada penelitian ini adalah seluruh WUS yang berada di Wilayah Kerja Puskesmas Lubuk Buaya Padang dengan 10 orang sampel. Peneliti menggunakan kuesioner untuk mengukur motivasi personal hygiene genetalia pada WUS sebelum dan sesudah pemberian intervensi peer education. Teknik analisa yang digunakan adalah analisa univariat yang digunakan untuk melihat motivasi personal hygiene genetalia sebelum dan sesudah diberikan intervensi dan analisa bivariat untuk melihat pengaruh peer education terhadap motivasi. Menggunakan uji paired sample t-test karena data terdistribusi normal.

HASIL

Tabel 1

Motivasi Sebelum diberikan Peer Education pada Wanita Usia Subur (WUS) di Kelurahan Lubuk Buaya RW XV Padang $(n=10)$

\begin{tabular}{cccccc}
\hline Motivasi & $\mathbf{n}$ & Mean & Min & Max & SD \\
\hline $\begin{array}{c}\text { Rata-rata sebelum } \\
\text { diberikan peer }\end{array}$ & 10 & 83.50 & 75 & 99 & 8.822 \\
& & & & &
\end{tabular}
education

Dari tabel 1 didapatkan hasil bahwa diperoleh rata-rata motivasi sebelum sebelum diberikan peer education diberikan intervensi peer education skor terendah ss yaitu 75. yaitu 83.50. Dari 10 orang WUS,

Tabel 2.

Motivasi Setelah diberikan Peer Education pada Wanita Usia Subur (WUS) di Kelurahan Lubuk Buaya RW XV Padang $(n=10)$

\begin{tabular}{|c|c|c|c|c|c|}
\hline Motivasi & $\mathrm{n}$ & Mean & Min & Max & SD \\
\hline $\begin{array}{l}\text { Rata-rata setelah } \\
\text { diberikan peer } \\
\text { education }\end{array}$ & 10 & $\begin{array}{l}105.0 \\
0\end{array}$ & 94 & 112 & 5.715 \\
\hline
\end{tabular}

Dari tabel 1 didapatkan hasil bahwa berdasarkan nilai mean didapatkan diperoleh rata-rata motivasi sebelum hanya $30 \%$

diberikan intervensi peer education yaitu 83.50. Dari 10 orang WUS, sebelum diberikan peer education diperoleh skor tertinggi yaitu 99 dan skor terendah yaitu 75 . sebelum diberikan intervensi peer education tentang personal hygiene genetalia

Rini Rahmayanti ${ }^{1}$, Isesreni ${ }^{2}$

${ }^{1}$ Dosen STIKes MERCUBAKTIJAYA Padang. Email : rinie.rahmayanti@gmail.com

${ }^{2}$ Dosen STIKes MERCUBAKTIJAYA Padang. Email : isesreni08@gmail.com 


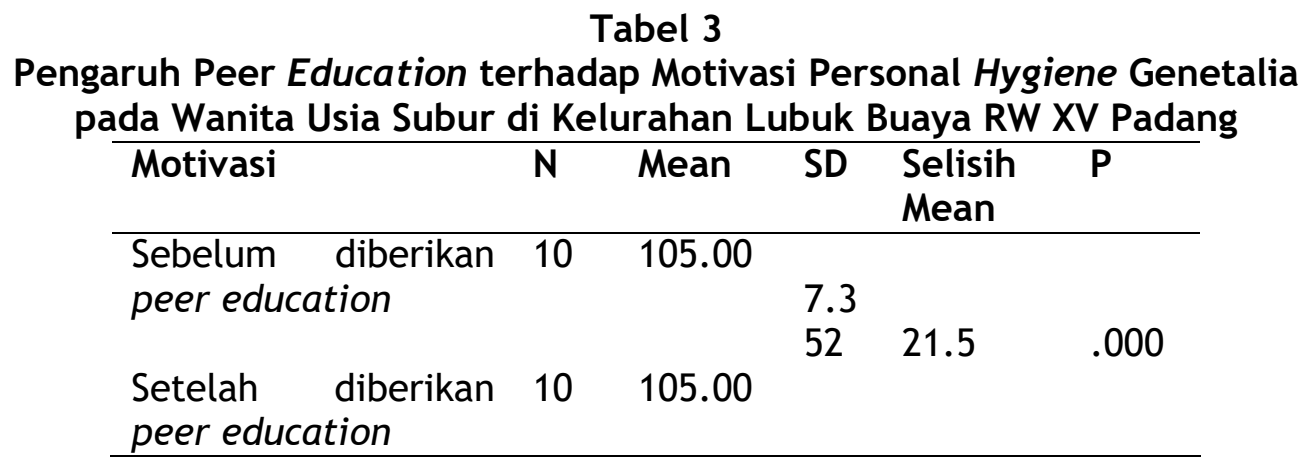

Berdasarkan tabel 3 hasil $u j i$ statistik yang diperoleh nilai hitung uji paired $T$-test didapatkan $p=0,000 \quad(p<0,05) \quad$ yang artinya terdapat pengaruh peer education

\section{PEMBAHASAN}

Rendahnya motivasi wanita usia subur dalam hygiene genetalia disebabkan oleh kurangnya mendapatkan informasi mengenai personal hygiene genetalia hal ini dibuktikan 10 orang WUS dari hasil kuesioner hanya 2 orang WUS yang pernah mendapatkan informasi terkait hygiene genetalia dan semua responden (10 orang) tidak pernah mendapatkan informasi kesehatan secara umum melalui orang lain. Berdasarkan informasi dari pihak Puskesmas memang pemaparan pendidikan kesehatan tidak pernah langsung diserahkan kepada masyarakat baik itu kader sekalipun karena masih kurangnya ketertarikan untuk saling berbagi informasi di wilayah tersebut, jadi yang menyampaikan pendidikan kesehatan biasanya adalah tenaga kesehatan.

Menurut Usman (2014) motivasi adalah daya upaya yang mendorong seseorang untuk melakukan sesuatu, sebagai daya penggerak dari dalam subjek untuk melakukan aktivitas tertentu untuk mencapai suatu tujuan (Sardiman, terhadap motivasi personal hygiene genetalia dalam pencegahan kanker serviks pada wanita usia subur (WUS) di Kelurahan Lubuk Buaya RW XV Padang.

2007). Beberapa teori dan definisi tentang motivasi maka dapat dipahami bahwa bila pada individu terdapat bermacam-macam motif yang mendorong dan menggerakkan manusia untuk melakukan kegitankegiatan dalam mencapai tujuan serta memenuhi kebutuhan hidup dalam rangka mempertahankan eksistensinya.

Informasi dapat diperoleh dari apapun termasuk dalam bentuk visual, audio, dan audiovisual. Menurut Mubarak (2007) semakin mudah suatu informasi untuk diakses, maka akan semakin mudah pula informasi tersebut dapat diterima oleh individu dan dapat memberikan perubahan perilaku kearah positif. Media adalah alat yang digunakan untuk menyampaikan pesan dari komunikator kepada khalayak. Informasi mengenai kesehatan reproduksi jarang disampaikan karena masyarakat menilai hal tersebut tabu untuk diperbincangkan.

Ranupandojo dan Husnan (2006) mengatakan dalam proses motivasi terdapat empat komponen

Rini Rahmayanti ${ }^{1}$, Isesreni ${ }^{2}$

${ }^{1}$ Dosen STIKes MERCUBAKTIJAYA Padang. Email : rinie.rahmayanti@gmail.com

${ }^{2}$ Dosen STIKes MERCUBAKTIJAYA Padang. Email : isesreni08@gmail.com 
terjadinya motivasi yaitu kebutuhan, dorongan, tindakan, dan kepuasan. Setiap individu mempunyai kebutuhan yang kekuatannya berbeda antara satu dan lainnya, sehingga akan menimbulkan dorongan kebutuhan yang tidak seimbang yang dilakukan melalui tindakan-tindakan atau kegiatan-kegiatan untuk mencapai tujuan, dan setelah mencapai tujuan melalui tindakan tadi barulah akan terasa terpuaskan. Jadi, ketika WUS tidak mengetahui hal yang terkait dengan hygiene genetalia maka WUS tidak merasa adanya kebutuhan. Karena tidak merasa adanya kebutuhan mengenai hygiene genetalia yang baik maka dorongan untuk melakukannyapun menjadi lemah atau kurang.

Setelah diberikan intervensi peer education tentang personal hygiene genetalia sebanyak 1 kali dalam seminggu dan dilakukan selama 2 minggu didapatkan peningkatan motivasi WUS dalam personal hygiene genetalia khususnya dalam upaya pencegahan kanker serviks. Hal ini menunjukkan bahwa pemberian peer education dapat meningkatkan motivasi personal hygiene genetalia pada WUS di RW XV Kelurahan Lubuk Buaya Padang.

Pada metode peer education ini melibatkan teman sebayanya membuat WUS lebih banyak bertanya dan tidak malu mengungkapkan pendapat dan isi hatinya sehingga WUS mampu memahami, mengaplikasikan dan mengevaluasi pengetahuan yang mereka peroleh. WUS merasa ada kesamaan antar anggota kelompok sehingga antar anggota dapat memberikan umpan balik yang positif guna untuk meningkatkan motivasinya. Ketika motivasi dalam personal hygiene genetalia meningkat maka perubahan perilaku kearah yang lebih baik juga akan terjadi dalam mencapai suatu tujuan salah satunya adalah pencegahan kanker serviks.

Menurut Wahjo Sumidjo dalam Usman (2014) mengklasifikasikan motivasi menjadi faktor internal diantaranya keperibadian, sikap, pengalaman, dan cita-cita, serta faktor eksternal diantaranya lingkungan (fisik, biologis, dan sosial), pendidikan, agama, sosial, ekonomi, kebudayaan, orangtua, dan saudara. Pengaruh lingkungan baik fisik, biologi, maupun lingkungan sosial yang ada disekitar individu dapat mempengaruhi tingkah laku individu tersebut sehingga dorongan dan pengaruh lingkungan akan dapat meningkatkan motivasi individu untuk melakukan sesuatu.

Salah satu upaya yang dapat dilakukan untuk meningkatkan pengetahuan tentang kesehatan adalah pendidikan kesehatan. Pendidikan kesehatan adalah seluruh bentuk upaya yang direncanakan ataupun ditujukan untuk mempengaruhi orang lain baik individu, kelompok, ataupun masyarakat sehingga mereka melakukan apa yang diharapkan oleh pelaku pendidikan kesehatan (Notoadmojo, 2012).

Peran peer educator dalam pelaksanaan penelitian ini juga berperan penting. Peer educator juga merupakan WUS yang berperan aktif dimasyarakat yaitu salah satu kader KB di daerah tersebut sehingga cara penyampaian dan penggunaan bahasa lebih dapat digunakan dengan baik sehingga tidak ada kesan menggurui melainkan sharing. Menurut Notoadmojo (2007) informasi yang

Rini Rahmayanti ${ }^{1}$, Isesreni ${ }^{2}$

${ }^{1}$ Dosen STIKes MERCUBAKTIJAYA Padang. Email : rinie.rahmayanti@gmail.com

${ }^{2}$ Dosen STIKes MERCUBAKTIJAYA Padang. Email : isesreni08@gmail.com 
akurat juga tergantung dari sumber informasi.

Kelebihan metode peer education dari metode pendidikan kesehatan lainnya inilah yang dapat meningkatkan motivasi WUS dalam hygiene genetalia. Menurut BKKBN (2008) metode peer education lebih baik digunakan dalam penyampaian informasi terkait dengan kesehatan reproduksi karena hal tersebut dirasa lebih sensitif dan lebih baik dibicarakan didalam kelompoknya sendiri.

Adanya pengaruh peer education terhadap motivasi personal hygiene genetalia dalam pencegahan kanker serviks pada wanita usia subur (WUS) di Kelurahan Lubuk Buaya RW XV Padang terjadi karena selama proses intervensi, peer educator yang telah mendapatkan pelatihan bisa menyampaikan pemahaman terkait personal hygiene genetalia serta responden dapat bekerjasama selama intervensi.

Keberhasilan pelaksanaan peer education juga terletak pada peer educator yang terlatih dan berkapabilitas. Peer educator harus dipilih dengan baik dan cermat dengan mempertimbangkan kredibilitasnya dengan kelompok sasaran (Bleeker, 2001, dalam Hulu, 2005). Peer educator yang dipilih dalam penyampaian informasi adalah orang yang berada disekitar lingkunganya dengan kriteria diantaranya adalah aktif dalam kegiatan sosial dan popular di lingkungannya, lancar membaca dan menulis, memiliki ciri-ciri kepribadian antara lain ramah, lancar dalam mengemukakan pendapat, luwes dalam pergaulan, berinisiatif dan kreatif, terbuka untuk hal-hal baru, dan lain-lain.
Peer Education atau pendidikan sebaya, merupakan sistem penyampaian sex education melalui pendidikan teman sebaya. Peer education dinilai efektif dalam penyampaian infromasi kesehatan reproduksi karena kesehatan reproduksi adalah masalah yang sensitif untuk dibicarakan, oleh karena itulah teman sebaya dapat dijadikan alternatif dalam penyampaian informasi terkait masalah kesehatan reproduksi yang sedang dialami. Hal ini juga dikarenakan penjelasan yang diberikan oleh teman sebayanya sendiri akan lebih mudah dipahami.

\section{KESIMPULAN}

Rata-rata motivasi WUS sebelum diberikan peer education adalah 83,50. Rata-rata motivasi WUS setelah diberikan peer education adalah 105.00. A da pengaruh peer education terhadap motivasi personal hygiene genetalia dalam pencegahan kanker serviks pada wanita usia subur (WUS) di Kelurahan Lubuk Buaya RW XV Padang dengan $P$-value $=0,000$ $(<0,05)$.

\section{SARAN}

Hasil penelitian ini dapat dijadikan sebagai informasi bagi tenaga kesehatan dalam upaya meningkatkan motivasi wanita usia subur untuk melakukan hygiene genitalia.

\footnotetext{
Rini Rahmayanti ${ }^{1}$, Isesreni ${ }^{2}$

${ }^{1}$ Dosen STIKes MERCUBAKTIJAYA Padang. Email : rinie.rahmayanti@gmail.com

${ }^{2}$ Dosen STIKes MERCUBAKTIJAYA Padang. Email : isesreni08@gmail.com
} 


\section{DAFTAR PUSTAKA}

Badan Penelitian dan Pengembangan Kesehatan (Balitbangkes) Kemenkes. (2013). Riset Kesehatan Dasar 2012. Jakarta : Balitbangkes Depkes

BKKBN. (2008). Kurikulum dan Modul Pelatihan Pemberian Informasi Kesehatan Reproduksi Remaja Oleh Pendidik Sebaya. Jakarta : Direktorat Remaja dan Perlindungan

Hak-Hak Reproduksi, BKKBN

Cahya, K Agnesia. (2017). Pengaruh Pendidikan Kesehatan Melalui Peer Group terhadap Perilaku Hygiene Menstruasi pada Siswi Kelas VIII di SMP 4 Gamping Sleman Yogyakarta. (digilib.unisayogya.ac.id/.../NA SKAH\%20PUB\%20AGNESIA\%2OKAR UNIA\%2OCAH...) diakses tanggal 28 Mei 2018

Effendi, U. (2014). Asas Manajemen Edisi Kedua. Jakarta : PT. Raja Grafindo Persada

Hartati. (2010). Cegah dan Deteksi Kanker Serviks. Jakarta : Elex Media Komputindo

Kasih, C. Laras. (2015). Efektivitas Peer Education pada Pengetahuan dan Sikap Siswa SMA dalam Mencegah HIVIAIDS. (www.jurnal.unsyiah.ac.id/JIK/ article/download/5284/4427), diakses tanggal 13 April 2018

Kementerian Kesehatan RI. (2015). Stop Kanker. Pusat Data dan Informasi Kementerian Kesehatan RI : Jakarta
Manuaba, I.A. C., Manuaba, I.B.G.F. (2009). Keluarga Berencana. Dalam Manuaba, I.A.C., Manuaba, I.B.G.F. (eds). Memahami Kesehatan Reproduksi Wanita. Edisi 2. Jakarta : EGC

Notoadmojo, S. (2010). Promosi Kesehatan : Teori Pengetahuan dan Prilaku, Edisi Revisi. Jakarta : Rineka Cipta

Purwanti, Y. (2017). Pengaruh Peer Education terhadap Peningkatan Pengetahuan dan Sikap Tentang HIVIAIDS.

(eprints.umsida.ac.id/356/1/Ar tikel\%20peer\%20education.pdf), diakses tanggal 28 Juni 2018

Rahmayanti. N. (2012). Perilaku Perawatan Kebersihan Alat Reproduksi dalam Pencegaha Kanker Serviks pada Siswi SMN 9 Kebon Pala Jakarta Timur. Jakarta : Universitas Indonesia (online) (http....) diakses tanggal 20 Desember 2017

Rasjidi, I. (2009). Deteksi Dini \& Pencegahan Kanker pada Wanita. Jakarta : Sagung Seto

Rofi'ah, Siti, dkk. (2017). Efektivitas Pendidikan Kesehatan Metode Peer Group terhadap Tingkat Pengetahuan dan Sikap Personal Hygiene Saat Menstruasi.

Sugiyono. (2011). Statistik Untuk Penelitian. Bandung : Alfabeta

Sriasih, NGK. (2013). Pengaruh Pendidikan Seksualitas Remaja Oleh Pendidik Sebaya Terhadap Pengetahuan dan Sikap Remaja Tentang Bahaya Seks Bebas :

Rini Rahmayanti ${ }^{1}$, Isesreni ${ }^{2}$

${ }^{1}$ Dosen STIKes MERCUBAKTIJAYA Padang. Email : rinie.rahmayanti@gmail.com

${ }^{2}$ Dosen STIKes MERCUBAKTIJAYA Padang. Email : isesreni08@gmail.com 
Denpasar : Poltekkes Denpasar (online) (http....) diakses tanggal 21 Desember 2017)

Wijaya D. (2010). Pembunuh Ganas Itu Bernama Kanker Serviks. Yogyakarta : Sinar Kejora

Wiratini. (2015). Pengaruh Peer Education Terhadap Perilaku Merokok Pada Remaja Di SMAN $X \quad$ Denpasar (online). (https://ojs.unud.ac.id/index.p hp/coping/article/view/13882) diakses tanggal 31 Mei 2018

World Health Organization (WHO), (2013). Comprehensive cervical cancer preventionandcontrol(Online). $(\underline{h}$ ttp://www. who.int/immunizati on/hpv/learn/comprehensive_c ervical_cancer_who_2013.pdf) diakses tanggal 21 Desember 2016

Yayasan Kanker Indonesia. (2012). Deteksi Dini Kanker Serviks. (Online)

(http: / /yayasankankerindonesia .org/2012), diakses tanggal 1 Januari 2018

Zulfa, I Rizka. (2011). Pengaruh Peer Education terhadap Sikap Manajemen Hygiene Menstruasi pada Santriwati Remaja Awal di Pondok Pasantren Al-Qodiri Kabupaten Jember. (repository.unej.ac.id/bitstrea $\mathrm{m} /$ handle/.../6090/Rizka\%20lnd ana\%20Zulva_1.pdf?...) diakses tanggal 15 April 2018. 